\title{
Lack of insulinotropic effect of endogenous and exogenous cholecystokinin in man
}

\author{
J. Reimers ${ }^{1}$, M. Nauck ${ }^{1}$, W.Creutzfeldt ${ }^{1}$, J.Strietzel ${ }^{1}$, R. Ebert ${ }^{1}$, P. Cantor ${ }^{3}$ and G. Hoffmann ${ }^{2}$ \\ ${ }^{1}$ Division of Gastroenterology and Endocrinology, Department of Medicine, and ${ }^{2}$ Department of Paediatrics, Georg August University, \\ Göttingen, FRG and ${ }^{3}$ Department of Clinical Chemistry, Rigshospitalet, Copenhagen, Denmark
}

\begin{abstract}
Summary. Intraduodenal phenylalanine administration ( $333 \mathrm{mg} / \mathrm{min}$ over $60 \mathrm{~min}$ ) released endogenous cholecystokinin in healthy young subjects as demonstrated radioimmunologically and by intraduodenal bilirubin and pancreatic enzyme output. Concomitantly, there was only a small increase over basal in circulating immunoreactive-insulin and immunoreactive-C-peptide concentrations. In healthy volunteers intraduodenal infusions of saline $(10 \mathrm{ml} / \mathrm{min})$, glucose $(333 \mathrm{mg} / \mathrm{min})$ or phenylalanine $(333 \mathrm{mg} / \mathrm{min})$ were performed for 60 min when plasma glucose was clamped at approximately $8 \mathrm{mmol} / 1$. Phenylalanine enhanced immunoreactive-insulin and immunoreactive-C-peptide responses three-fold more than did the same amount of glucose. Immuno-reactive gastric inhibitory polypeptide responses were small and not different after glucose and phenylalanine administration. Immunoreactive cholecystokinin was significantly stimulated to $9.4 \pm 1.4 \mathrm{pmol} / \mathrm{l}$ only by intraduodenal phenylalanine. Plasma phenylalanine concentrations increased into the supraphysiological range (approximately $1.5 \mathrm{mmol} / \mathrm{l})$. Intravenous infusions of phenylalanine achieving plasma concentrations of $1.2 \mathrm{mmol} / \mathrm{l}$ stimulated insulin
\end{abstract}

secretion at elevated plasma glucose concentrations (approximately $8 \mathrm{mmol} / \mathrm{l}$ clamp experiments), but had no effect at basal plasma glucose concentrations. A small increase in cholecystokinin also was observed. Intravenous infusions of synthetic sulphated cholecystokinin- 8 leading to plasma concentrations in the upper postprandial range $(8-12 \mathrm{pmol} / \mathrm{l})$ did not augment the immunoreactive-insulin or immunoreactive-C-peptide levels during hyperglycaemic clamp experiments, in the absence or presence of elevated plasma phenylalanine concentrations. It is concluded that the augmentation of the glucose-induced insulin release by intraduodenal administration of phenylalanine cannot be related to cholecystokinin release, but rather is explained by the combined effects of elevated glucose and phenylalanine concentrations. In man, cholecystokinin does not augment insulin secretion caused by moderate hyperglycaemia, elevations of phenylalanine concentrations, or combinations thereof.

Key words: Enteroinsular axis, incretin effect, cholecystokinin, gastric inhibitory polypeptide, insulin secretion, phenylalanine, amino acids.
After the ingestion of meals, insulin secretion is stimulated by a rise in glycaemia. In addition, insulinotropic gastrointestinal hormones are released, which stimulate pancreatic $B$ cells via the enteroinsular axis $[1,2]$. This phenomenon is called the incretin effect $[3,4]$ and is responsible for up to $60 \%$ of the amount of insulin secreted in response to an oral glucose load $[5,6]$. In man, gastric inhibitory polypeptide (GIP) is regarded as the main incretin candidate after glucose ingestion. GIP is released during the process of glucose absorption [7] and enhances the insulin response to hyperglycaemia [8]. However, after a mixed meal, additional insulinotropic hormones may be released by the protein or fat content of the food, which have not been considered typical incretins, because they are not released by glucose ingestion.

Until a few years ago most cholecystokinin (CCK) preparations were contaminated with GIP. Therefore, the insulinotropic effect described for CCK may have been due to GIP. In more recent studies, CCK has been shown to augment the insulin response to hyperglycaemia in rats [9-12] and dogs [13], but not in pigs [14]. In rat pancreatic islets, specific CCK binding sites have been demonstrated $[15,16]$. Whether cholecystokinin, which is released after the ingestion of amino acid and fat containing meals [17-19], may act as an insulinotropic hormone in man is less clear. A recent study suggested that intravenous infusions leading to physiological concentrations of CCK-8 enhanced the insulin response to intravenous arginine and mixed amino acids, but not glucose infusions [20].

It was the aim of this study to elucidate the role, in healthy man, of endogenously-secreted cholecystokinin and of intravenously administered exogenous 
CCK-8, as an incretin hormone, during euglycaemic and hyperglycaemic clamp experiments. Part of the results have been communicated in abstract form [45, 46].

\section{Subjects and methods}

\section{Experimental design}

Healthy volunteers without a personal or family history of diabetes participated in six experimental protocols (subject characteristics, Table 1). All gave informed consent after the procedures and possible risks had been explained. The study protocol was approved by the committee for ethics in human research of the Medical Faculty at the Georg-August-University in Göttingen on May 13, 1986.

Protocol (a), duodenal perfusion with phenylalanine solutions. In five male subjects, a double lumen duodenal tube was positioned under fluoroscopic control with openings in the upper and mid part of the duodenum (for infusion of phenylalanine solutions) and behind the ligament of Treitz (for continuous aspiration of duodenal contents).

Protocol (b), hyperglycaemic clamp experiments with intraduodenal infusions of saline (control), glucose, or phenylalanine. Eight subjects were studied on three occasions, the different experiments being performed in randomised order. Double lumen tubes were positioned under fluoroscopic control with openings in the antral region of the stomach (for continuous aspiration of gastric juice) and in the mid and lower part of the duodenum for the infusion of saline, glucose, or phenylalanine solutions.

Protocol (c), intravenous infusion of sulphated cholecystokinin-8 during a hyperglycaemic clamp experiment. Of the 8 subjects participating in protocol (b), 6 took part in an additional experiment, which was carried out in the same way as the hyperglycaemic clamp experiment with intraduodenal saline infusion. Synthetic sulphated CCK-8 was infused intravenously.

Protocol (d), intravenous infusions of phenylalanine during hyperglycaemic clamp experiments at a rate that elevates plasma phenylalanine concentrations into the upper physiological range. Eight subjects participated.

Protocol (e), intravenous infusions of phenylalanine during hyperglycaemic clamp experiments at a rate that elevates plasma phenylalanine concentrations into a similar range as observed during intraduodenal administrations of phenylalanine $(20 \mathrm{~g} / \mathrm{h})$. Six subjects participated.

Protocol $(f)$, intravenous infusions of phenylalanine under basal conditions at a rate that elevates plasma phenylalanine concentrations into a similar range as observed during intraduodenal administration of phenylalanine $(20 \mathrm{~g} / \mathrm{h})$. Three subjects participated.

\section{Experimental procedures}

All studies were performed in the morning after an overnight fast. Two intravenous cannulas were placed into forearm veins. Infusions of glucose, saline, and CCK-8, and removal of blood specimens were performed on contralateral arms.

Protocol (a). Approximately $30 \mathrm{~min}$ after positioning the duodenal tube, a perfusion with $0.9 \% \mathrm{NaCl}, \mathrm{pH} 6.0,37^{\circ} \mathrm{C}, 10 \mathrm{ml} / \mathrm{min}$, was started. After $60 \mathrm{~min}$, the perfusate was changed to contain phenylalanine (for biochemical purposes, Merck AG, Darmstadt, FRG), $20 \mathrm{~g} / 600 \mathrm{ml}(202 \mathrm{mmol} / 1)$, made isoosmolar to plasma with additions of $\mathrm{NaCl}$, adjusted to $\mathrm{pH} 6.0$, and warmed to $37^{\circ} \mathrm{C}$. The infusion rate was $10 \mathrm{ml} / \mathrm{min}(121 \mathrm{mmol} / \mathrm{h})$. At $120 \mathrm{~min}$, the phenylalanine solution was again replaced by saline. Blood was drawn before and at $30 \mathrm{~min}$ intervals during the intraduodenal perfusion for the determination of plasma glucose, immunoreactive (IR)-insulin, IRC-peptide, IR-CCK, and phenylalanine concentrations. The duodenal content was continuously aspirated from the distal duodenum
Table 1. Subject characteristics of healthy volunteers participating in the studies

\begin{tabular}{lllllll}
\hline Protocol & Number & $\begin{array}{l}\text { Sex } \\
\text { M/F }\end{array}$ & Age & Height & Weight & $\begin{array}{l}\text { Body mass } \\
\text { index } \\
\left(\mathrm{kg} / \mathrm{m}^{2}\right)\end{array}$ \\
\hline (a) & 5 & $5 / 0$ & $25 \pm 3$ & $185 \pm 8$ & $79 \pm 5$ & $23.3 \pm 0.9$ \\
(b) & 8 & $8 / 0$ & $26 \pm 1$ & $180 \pm 8$ & $74 \pm 10$ & $22.9 \pm 1.9$ \\
(c) & 6 & $6 / 0$ & $26 \pm 1$ & $181 \pm 9$ & $77 \pm 9$ & $23.5 \pm 1.7$ \\
(d) & 8 & $3 / 5$ & $25 \pm 2$ & $173 \pm 9$ & $63 \pm 12$ & $21.0 \pm 2.1$ \\
(e) & 6 & $3 / 3$ & $25 \pm 2$ & $176 \pm 11$ & $65 \pm 13$ & $20.7 \pm 2.3$ \\
(f) & 3 & $2 / 1$ & $25 \pm 2$ & $180 \pm 3$ & $69 \pm 4$ & $21.1 \pm 1.2$ \\
\hline
\end{tabular}

Mean \pm SD. Some subjects participated in more than one study

and collected in $15 \mathrm{~min}$ fractions for the measurement of bilirubin, trypsin, and $\alpha$-amylase.

Protocol (b). Approximately $30 \mathrm{~min}$ after positioning the duodenal tube, a $180 \mathrm{~min}$ hyperglycaemic clamp was initiated aiming at a stable plasma glucose value of $8 \mathrm{mmol} / \mathrm{l}$. Glucose $(20 \%$ in water) was injected (approximately $0.12 \mathrm{~g} / \mathrm{kg}$ body weight). The glucose infusion rate necessary to keep the desired plasma concentration was adjusted according to repeated plasma glucose measurements performed at 5 min intervals (Beckman Glucose Analyser 2, Beckman Instruments, Munich, FRG). Glucose infusion rates were protocolled in order to serve as a measure of the biological activity of circulating insulin concentrations [21]. At $60 \mathrm{~min}$, an intraduodenal infusion was started containing saline, glucose, or phenylalanine. The infusion rates were $10 \mathrm{ml} / \mathrm{min}$. All solutions were made isoosmolar to plasma by adding appropriate amounts of $\mathrm{NaCl}$, adjusted to $\mathrm{pH} 6.0$, and prewarmed to $37^{\circ} \mathrm{C}$. Glucose and phenylalanine solutions contained identical amounts $(20 \mathrm{~g}$ in $600 \mathrm{ml})$ of the respective substrate. Intraduodenal infusions were stopped at min 120 . Blood was drawn before $\left(\mathrm{O}_{1}, \mathrm{O}_{2}\right)$ the start of the experiment and at min 15 , $30,45,60,75,90,105,120,150$, and 180 . Twenty-five min after starting the intraduodenal infusions, the duodenal content was aspirated for the measurement of bilirubin and trypsin concentrations. The infusions were interrupted for approximately $1 \mathrm{~min}$ for this purpose.

Protocol (c). The experiment was carried out exactly as the hyperglycaemic clamp with intraduodenal saline infusion. From min 60 to 120 , synthetic sulphated CCK-8 (Bachem Feinchemikalien, Bubendorf, Switzerland), was infused intravenously at a rate of $25 \mathrm{pmol}$. $\mathrm{kg}^{-1} \cdot \mathrm{h}^{-1}$, and four-fold this infusion rate during the initial $5 \mathrm{~min}$.

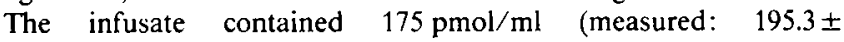
$10.9 \mathrm{pmol} / \mathrm{ml}, n=6) \mathrm{CCK}-8$, in physiological saline with an addition of human serum albumin, $2 \mathrm{~g} / \mathrm{l}$ (Rhodalbumin $20 \%$, salt-poor, Merieux, Norderstedt, FRG). Purity was checked by HPLC (one major peak) and by amino acid analysis. This solution was filtered through a Millipore filter (pore diameter $0.22 \mu \mathrm{m}$ ) and was pumped through infusion lines $30 \mathrm{~min}$ before starting intravenous infusions. Thus, absorption of CCK to syringes and tubes during the period of intravenous infusion was minimised. There was no difference in CCK content of the infusate before and after the period of infusion (data not shown).

Blood was drawn and duodenal aspirates were obtained as described for Protocol (b), except that the duodenal sample was aspirated 7.5 min after starting the intravenous infusion of CCK-8.

Protocol (d). The hyperglycaemic clamp was performed as described for Protocol (b). No duodenal tube was used. From min 60 to 120, a sterile and pyrogen free phenylalanine $(20 \mathrm{~g} / 1)$ solution (Braun Melsungen $A G$, Melsungen, FRG) was infused intravenously at a rate of $1.7 \mu \mathrm{mol} \cdot \mathrm{kg}^{-1} \cdot \mathrm{min}^{-1}$, and twice this infusion rate during the initial $10 \mathrm{~min}$. Each subject was studied on two occasions. In random order, placebo or sulphated CCK-8 (Peninsula Laboratories, Merseyside, England) were infused intravenously at a rate of $25 \mathrm{pmol}$. $\mathrm{kg}^{-1} \cdot \mathrm{h}^{-1}$, and four-fold this infusion rate during the initial $5 \mathrm{~min} . \mathrm{A}$ 
Table 2. Stimulation of pancreatic enzyme secretion, gall bladder contraction, and release of cholecy'stokinin during duodenal perfusions with phenylalanine $(333 \mathrm{mg} / \mathrm{min}$ over $60 \mathrm{~min})$. Duodenal content was continuously aspirated from the distal duodenum and collected in 15 -min fractions

\begin{tabular}{|c|c|c|c|c|c|c|}
\hline Parameter & $\begin{array}{l}\text { Basal } \\
\text { value }^{a}\end{array}$ & $\begin{array}{l}\text { Peak } \\
\text { value }\end{array}$ & Unit & $\begin{array}{l}\text { Time } \\
\text { to peak } \\
\text { (min) }\end{array}$ & $\begin{array}{l}0-120 \mathrm{~min} \\
\text { integrated } \\
\text { incremental } \\
\text { responses }\end{array}$ & Unit \\
\hline
\end{tabular}

\begin{tabular}{|c|c|c|c|c|c|c|}
\hline \multicolumn{7}{|l|}{ Duodenal output } \\
\hline Bilirubin & $1.4 \pm 0.8$ & $10.9 \pm 1.2^{\mathrm{h}}$ & $\mathrm{mg} / 15 \mathrm{~min}$ & $15-30$ & $18.9 \pm 8.7^{c}$ & $\mathrm{mg}$ \\
\hline
\end{tabular}

Mean \pm SEM, $n=5$. a Duodenal output during the last $15 \mathrm{~min}$ of or, respectively, plasma concentrations after 60 min of duodenal saline perfusion $(10 \mathrm{ml} / \mathrm{min})$. 'Significantly different (Student's paired t-test) from basal value $(p \leqq 0.05)$. 'Significantly different from zero (Student's t-test, $p \leqq 0.05$ )

Table 3. Experimental protocols and clamp conditions

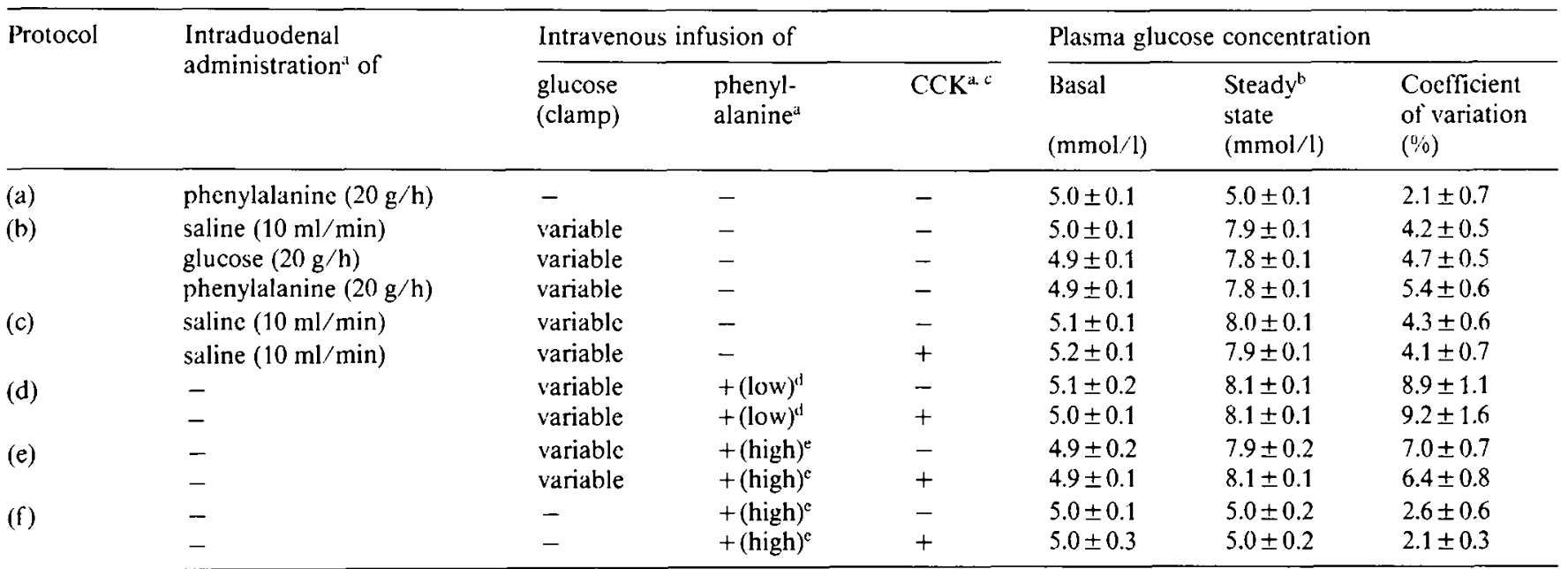

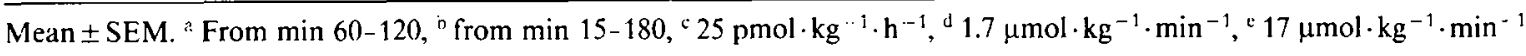

high purity ( $\geqq 99 \%$ ) was guaranteed by the supplier and checked by HPLC and amino acid analysis. The infusate was prepared as described for Protocol (b).

Protocol (e). The experiments were performed as described for Protocol (d), except that phenylalanine infusions were performed at a rate of $17 \mathrm{umol} \cdot \mathrm{kg}^{-1} \cdot \mathrm{min}^{-1}$.

Protocol $(f)$. The experiments were performed as described for Protocol (c). However, blood glucose was not elevated by intravenous glucose infusions.

Blood was drawn into heparinised tubes or (for the determination of IR-glucagon) into tubes containing EDTA $(5 \mathrm{mg})$ and aprotinin $(0.35 \mathrm{mg}$ or $2500 \mathrm{KIU}$, Trasylol, Bayer AG, Leverkusen, FRG), in a volume of $0.125 \mathrm{ml}$, and kept in ice until sedimenting blood cells by centrifugation.

Glucose was assayed immediately using a Beckman glucose analyser 2 (glucose oxidase method). Insulin immunoreactivity was determined in plasma according to Melani et al. [22] using human insulin as standard. Immunoreactive $\mathrm{C}$-peptide was measured using a commercial radioimmunoassay kit (Mallinckrodt Diagnostica, Dietzenbach, FRG). Immunoreactive CCK was estimated according to [23], using antiserum G-160 and sulphated CCK-8 for tracer preparation and as standard. Gastric inhibitory polypeptide was measured by the method of Kuzio et al. [24] using antibody Goe 5/76/9 and natural porcine GIP (purchased from Dr. J.C. Brown) as standard, with some modifications [25]. Immunoreactive gastrin was detcrmined as described by Mayer et al. [26] using antiserum 118/2/4A and human gastrin-17 (Serva Feinbiochemica, Heidelberg, FRG) for tracer preparation and as standard. Immunoreactive glucagon was measured using a commercial radioimmunoassay kit (Biodata Laboratories, obtained from Serono Diagnostika, Freiburg, FRG). Plasma phenylalanine and tyrosine concentrations were measured on an $\mathrm{Al}$ pha Plus Amino Acid Analyser (LKB Biochrom Ltd., Cambridge, England). In duodenal aspirates, bilirubin concentrations were measured according ot [27], trypsin [28] using the artificial substrate benzoyl arginine p-nitroanilide (Boehringer Mannheim, Mannheim, FRG), and $\alpha$-amylase according to [29] using starch as substrate and 3.5 dinitro salicylic acid as colour reagent.

\section{Statistical analysis}

Results are presented as mean $\pm \mathrm{SEM}$ for the number of determinations indicated. Integrated incremental responses are calculated according to the trapezoidal rule (minus mean baseline values). Significances of differences were estimated by paired or unpaircd Student's t-tests (two-tailed), when appropriate. Comparisons of group means between more than two experimental points (repeated measurements, three protocols) were carried out using Peritz' F test for multiple comparisons [30]. 


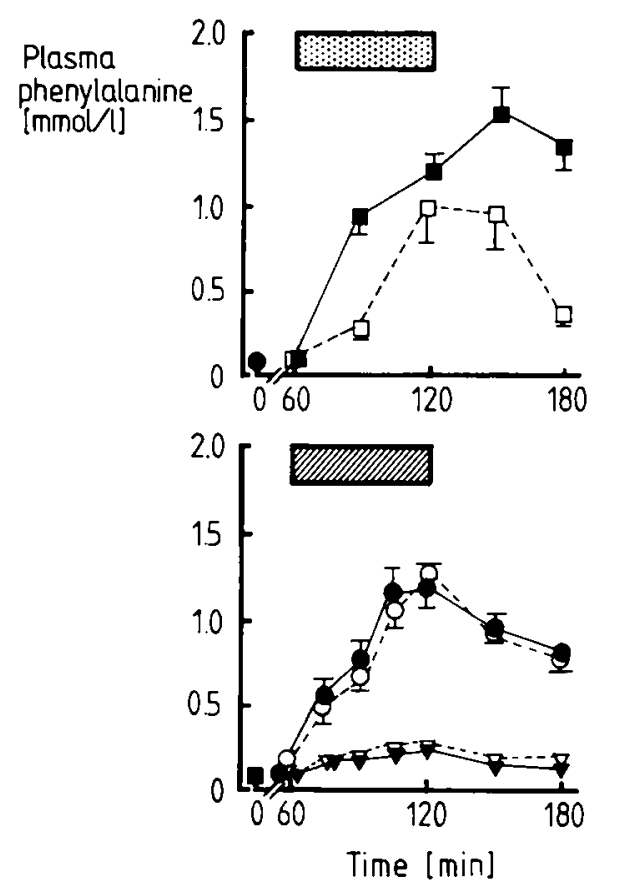

Fig. 1. Plasma phenylalanine concentrations during intraduodenal (upper panel) and intravenous (lower panel) administrations of phenylalanine. Dotted and hatched bars indicate the period of phenylalanine (and CCK) infusion. Symbols for the upper panel: $\square---\square$ : Perfusion under basal conditions with permanent withdrawal of jejunal contents. Infusion during hyperglycaemic clamp experiments. Symbols for the lower panel (intravenous infusion during hyperglycaemic clamp experiments): $\nabla \ldots \nabla ; \boldsymbol{\nabla}-\boldsymbol{\nabla}$ : low rate $\left(1.7 \mu \mathrm{mol} \cdot \mathrm{kg}^{-1} \cdot \mathrm{min}^{-1}\right) ; \mathrm{O}-. \mathrm{O} ; \longrightarrow$ : high rate $\left(17 \mu \mathrm{mol} \cdot \mathrm{kg}^{-1} \cdot \mathrm{min}^{-1}\right)$. Open symbols: Without exogenous $\mathrm{CCK}$. Closed symbols: with concomitant infusions of sulphated CCK -8

\section{Results}

\section{Intraduodenal administration of phenylalanine under basal (euglycaemic) conditions}

Duodenal perfusions with a phenylalanine solution (333 $\mathrm{mg} / \mathrm{min}$ ) increased exocrine pancreatic secretions (trypsin and amylase output). Gall bladder contraction was evident from a more than 10 -fold increase in bilirubin output, and invariably began 20 to $25 \mathrm{~min}$ after starting the intraduodenal phenylalanine administration. This biological evidence for the release and action of cholecystokinin was confirmed by radioimmunological measurement (Table 2). There was a slight increase in circulating IR-insulin (from basal $0.036 \pm 0.001$ to $0.071 \pm 0.006 \mathrm{nmol} / \mathrm{l}, p \leqq 0.05$ ) and IR-C-peptide (from basal $0.39 \pm 0.04$ to $0.52 \pm 0.03 \mathrm{nmol} / 1, p \leqq 0.05$ ) during the period of intraduodenal phenylalanine infusion, which was not accompanied by any change in plasma glucose concentrations $(5.0 \pm 0.1 \mathrm{mmol} / 1$, Table 3$)$. Phenylalanine concentrations increased from basal $0.04 \pm 0.00 \mathrm{mmol} / 1$ to $0.33 \pm 0.03 \mathrm{mmol} / 1$ after $30 \mathrm{~min}$ and to peak values of $1.19 \pm 0.08 \mathrm{mmol} / 1$ after $60 \mathrm{~min}$ (Fig. 1), accompanied by a smaller increase in plasma tyrosine concentrations from basal $0.04 \pm 0.01$ to $0.10 \pm 0.01 \mathrm{mmol} / \mathrm{l}$ (data not shown).

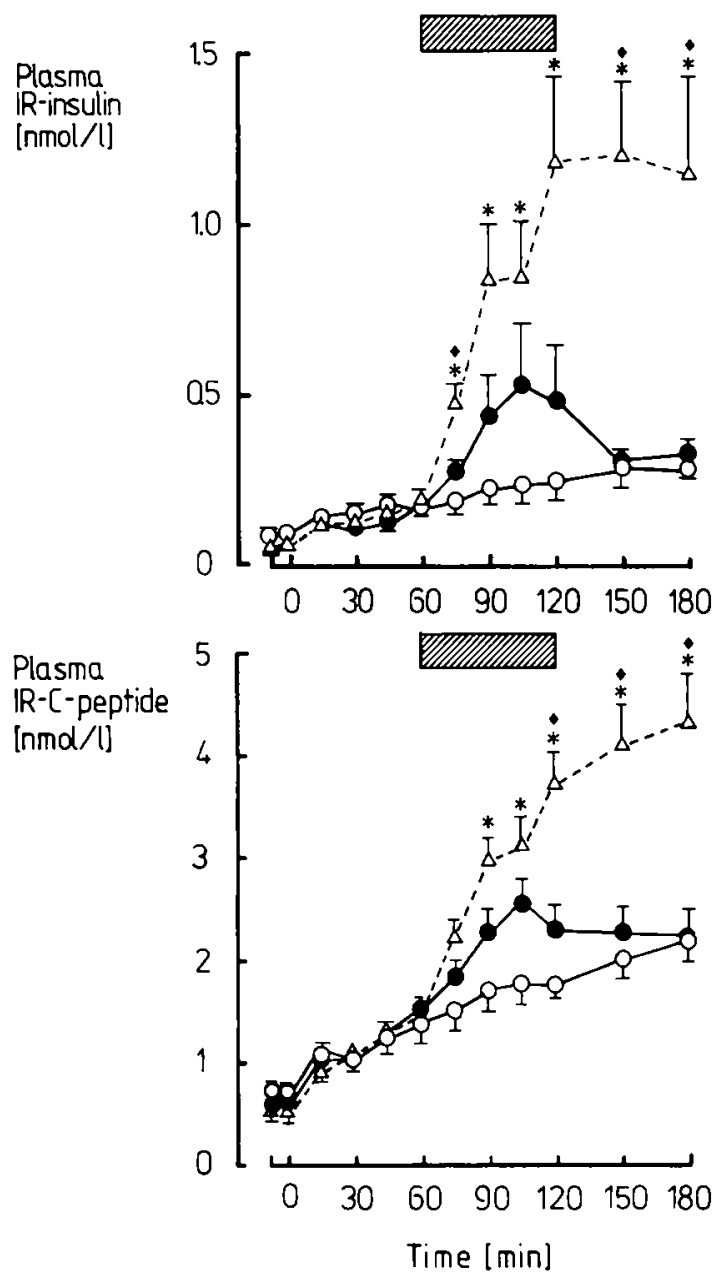

Fig. 2. Plasma IR-insulin (upper panel) and IR-C-peptide (lower panel) responses during hyperglycaemic clamp experiments (approximately $8 \mathrm{mmol} / \mathrm{l})$ with intraduodenal infusions $(10 \mathrm{ml} / \mathrm{min})$ of saline (control experiment $\mathrm{O}-\mathrm{O})$, glucose $(333 \mathrm{mg} / \mathrm{min}-\mathrm{O}$ ), and phenylalanine $(333 \mathrm{mg} / \mathrm{min} \Delta \cdots \Delta)$. Asterisks indicate significantly different value (Peritz' $F$ test, $p \leqq 0.05$ ) from the control experiment (saline infusion, $*$ ), or from the experiment with intraduodenal glucose administration $(\bullet)$. Hatched bars indicate the period of intraduodenal administration of saline, glucose, or phenylalanine, respectively

Intraduodenal administration of saline, glucose $(20 \mathrm{~g} / \mathrm{h})$, and phenylalanine $(20 \mathrm{~g} / \mathrm{h})$ during hyperglycaemic $(8 \mathrm{mmol} / \mathrm{l})$ clamp experiments

While maintaining a hyperglycaemic clamp (plasma glucose concentration $8.0 \mathrm{mmol} / 1$, Table 3), IR-insulin and IR-C-peptide concentrations rose gradually over the period of $180 \mathrm{~min}$ (Fig. 2). Therefore, in line with previous reports [31], it was necessary to increase the glucose infusion rate in the course of the experiments (Fig. 3). Intraduodenal infusions of a glucose solution $(333 \mathrm{mg} / \mathrm{min}$ administered over $60 \mathrm{~min})$ stimulated increases in IR-insulin (to $0.53 \pm 0.18 \mathrm{nmol} / \mathrm{I}$ at $105 \mathrm{~min}$ ) and IR-C-peptide (to $2.54 \pm 0.27 \mathrm{nmol} / \mathrm{l}$ at $105 \mathrm{~min}$, Fig.2). These values were higher than with intraduodenal saline infusions, although the difference did not reach statistical significance (Peritz' $F$ test, $p \leqq$ 
Table 4. Insulin secretion and cumulative glucose infusion rates necessary to maintain stable hyperglycaemia during clamp experiments

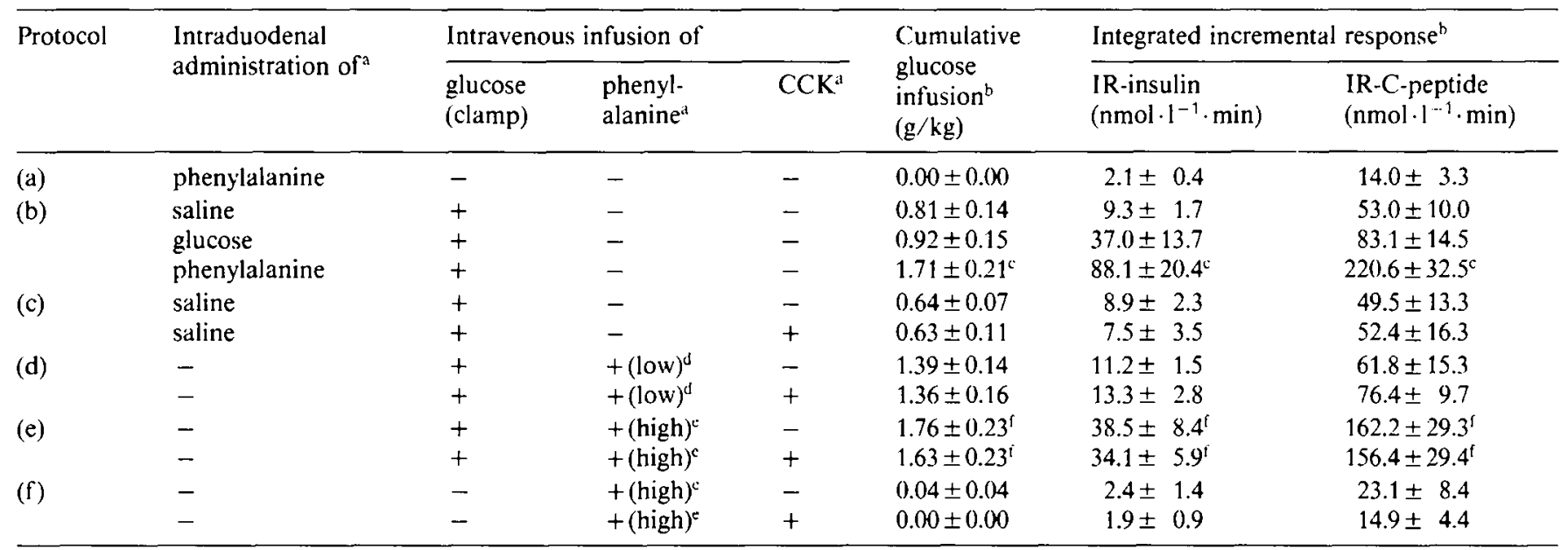

${ }^{a} \min 60-120,{ }^{b} \min 60 \cdot 180$ (i.e., after introduction of the stimuli), ${ }^{c}$ significant difference (Peritz' F-test, $p \leqq 0.05$ ) to the respective control experiment (intraduodenal saline infusion), ${ }^{d} 1.7 \mu \mathrm{mol} \cdot \mathrm{kg}^{-1} \cdot \mathrm{min}^{-1}{ }^{c}{ }^{c} 17 \mu \mathrm{mol} \cdot \mathrm{kg}^{-1} \cdot \mathrm{min}^{-1}$, ' significant difference (Student's t-test, $p \leqq 0.05$ ) to the respective control experiment (without intravenous phenylalanine infusion)

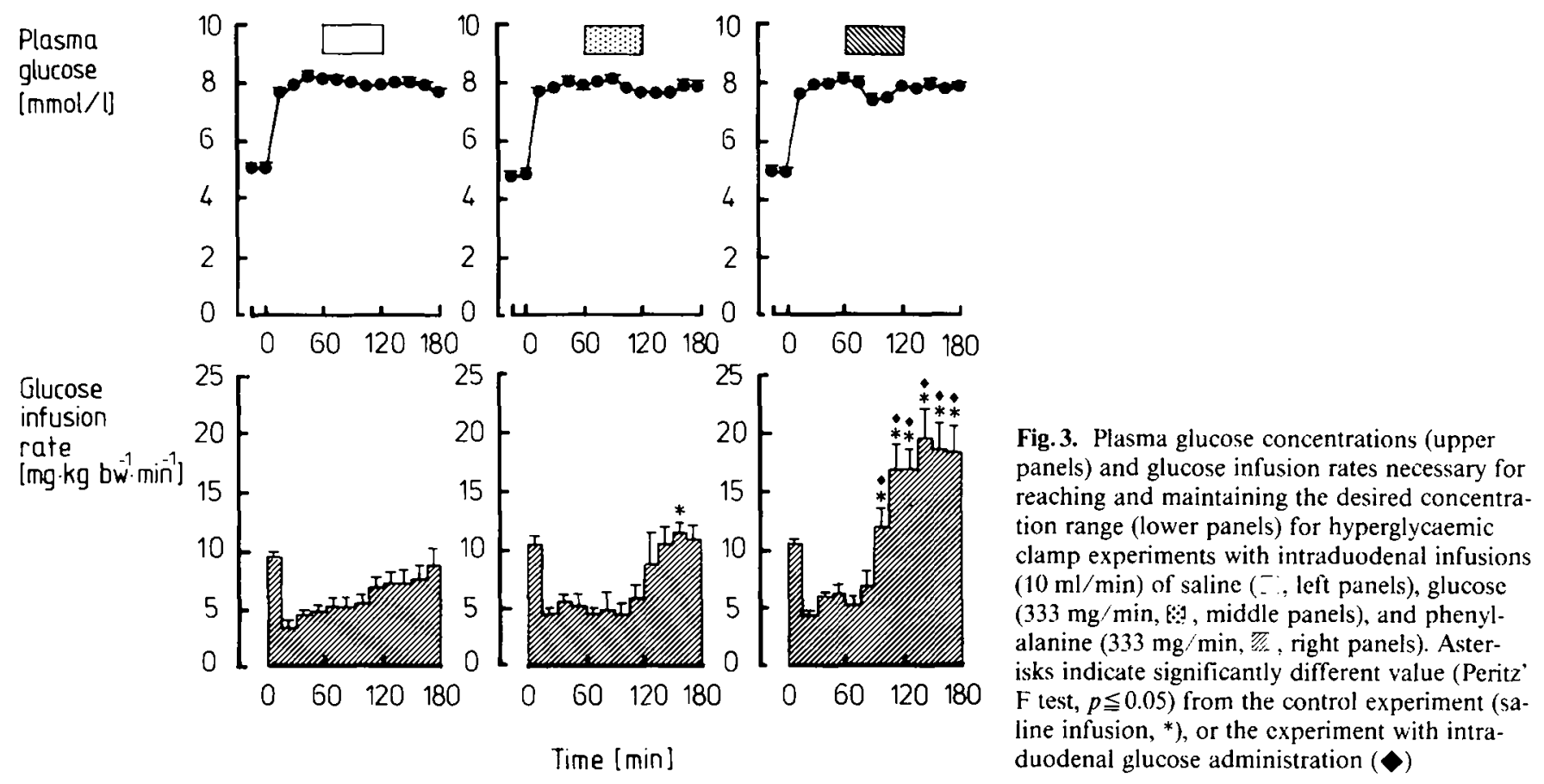

Table 5. Stimulation of gall bladder contraction and of pancreatic trypsin secretion: concentrations of bilirubin and trypsin in samples of duodenal content during intraduodenal infusions of saline $(10 \mathrm{ml} / \mathrm{min}$, control $)$, glucose $(333 \mathrm{mg} / \mathrm{min})$, and phenylalanine (333 $\mathrm{mg} / \mathrm{min})$, or during intravenous infusions of sulphated CCK-8 $\left(25 \mathrm{pmol} \cdot \mathrm{kg}^{-1} \cdot \mathrm{h}^{-1}\right)$. Hyperglycaemic clamp experiments (plasma glucose approximately: $8 \mathrm{mmol} / 1$ )

\begin{tabular}{lllllc}
\hline Protocol & Number & $\begin{array}{l}\text { Intraduodenal } \\
\text { infusion of }\end{array}$ & $\begin{array}{l}\text { Intravenous } \\
\text { infusion of }\end{array}$ & $\begin{array}{l}\text { Bilinubin } \\
\text { concentration } \\
(\mathrm{mg} / \mathrm{l})\end{array}$ & $\begin{array}{l}\text { Trypsin } \\
\text { concentration } \\
(\mathrm{U} / 1)\end{array}$ \\
\hline (b) & 8 & saline & glucose & $16 \pm 7$ & $84.1 \pm 46.4$ \\
& 8 & glucose & glucose & $18 \pm 13$ & $23.4 \pm 9.0$ \\
(c) & 8 & phenylalanine & glucose & $216 \pm 51^{\mathrm{a}}$ & $339.4 \pm 63.4^{\mathrm{a}}$ \\
& 6 & saline & glucose & $20 \pm 9$ & $106.9 \pm 78.9$ \\
\hline
\end{tabular}

Mean \pm SEM. Protocol (b): samples aspirated 25 min after starting intraduodenal infusions. Protocol (c): Samples aspirated 7.5 min after starting intravenous infusions of sulphated CCK-8. ' Significant difference ( $p \leqq 0.05$, Peritz' $F$-test) to experiments with intraduodenal saline or giucose. ${ }^{b}$ Significant difference ( $p \leqq 0.05$, Student's t-test) to experiments without CCK-infusions 
$0.05)$. Only towards the end of the experiment a higher glucose infusion rate was necessary (Fig.3, asterisk), indicating that the intraduodenal glucose infusion did not cover the increased glucose need.
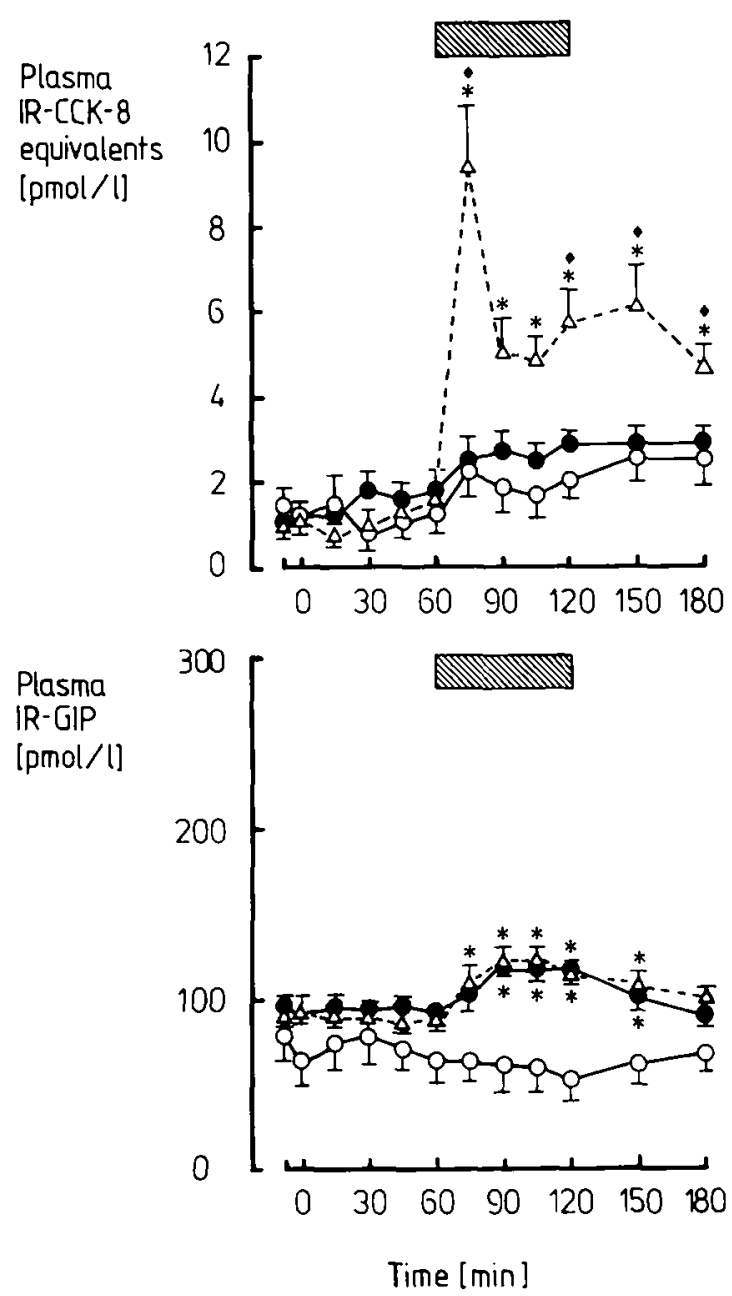

Fig.4. Plasma IR-CCK-8 equivalents' (upper panel) and IR-GIP (lower panel) responses during $180 \mathrm{~min}$ hyperglycaemic clamp experiments (approximately $8 \mathrm{mmol} / \mathrm{l}$ ) with intraduodenal infusions $(10 \mathrm{ml} / \mathrm{min})$ of saline (control experiment $\mathrm{O}-\mathrm{O}$ ), glucose $(333 \mathrm{mg} / \mathrm{min}-1)$, or phenylalanine $(333 \mathrm{mg} / \mathrm{min} \Delta-\Delta)$ from min $60-120$ (hatched bars). Asterisks indicate significantly different value (Peritz' $F$ test, $p \leqq 0.05)$ from the control experiment (saline infusion, *) or from the experiment with intraduodenal glucose administration $(\bullet)$
Intraduodenal administration of phenylalanine raised plasma phenylalanine concentrations from basal $0.05 \pm 0.01$ to $0.94 \pm 0.11 \mathrm{mmol} / 1$ after $30 \mathrm{~min}$ and to $1.18 \pm 0.08$ after 60 min (Fig. 1). Plasma phenylalanine concentrations rose further after cessation of intraduodenal infusions. This rise in phenylalanine concentrations was accompanied by a small increase in tyrosin levels from basal $0.06 \pm 0.01$ to $0.09 \pm 0.01 \mathrm{mmol} / 1$ after $60 \mathrm{~min}$ and to $0.11 \pm 0.02 \mathrm{mmol} / 1$ after $120 \mathrm{~min}$. IR-insulin increased (to $1.19 \pm 0.23 \mathrm{mmol} / \mathrm{l}$ at $150 \mathrm{~min}$ ) and IR-C-peptide rose (to $4.27 \pm 0.53 \mathrm{nmol} / 1$ at $180 \mathrm{~min}$ ). This elevation in IR-insulin and C-peptide persisted over the period of phenylalanine infusion. The IR-insulin and IR-C-peptide values reached as well as the integrated incremental areas (from the start of the intraduodenal infusion until the end of the experiments) were significantly greater than those during and after intraduodenal saline or glucose administration (Fig. 2, Table 4). As a consequence, more glucose had to be infused to maintain a plasma glucose concentration of $8 \mathrm{mmol} / \mathrm{l}$ (Fig. 3).

Only intraduodenal phenylalanine infusions led to higher concentrations of bilirubin and trypsin in duodenal aspirates (Table 5). The apparent stimulation of exocrine pancreatic secretion and gall bladder contraction is explained by the secretion and action of $\mathrm{CCK}$ as measured radioimmunologically (Fig. 4, upper panel, Table 6). Intraduodenal saline or glucose infusions did not release CCK as shown by the insignificant changes throughout the period of their intraduodenal administration. IR-GIP plasma concentrations increased slightly but significantly during both intraduodenal glucose and phenylalanine administration (Fig. 4, lower panel, Table 6).

IR-gastrin concentrations were stimulated in some, but not all subjects, by the intraduodenal administration of phenylalanine, from basal $4.9 \pm 2.8 \mathrm{pmol} / \mathrm{l}$ to $37.7 \pm 17.7 \mathrm{pmol} / 1$ at $120 \mathrm{~min}(p \leqq 0.05)$. IR-glucagon was depressed slightly by raising plasma glucose concentrations to $8 \mathrm{mmol} / \mathrm{l}$. There was no evidence for a stimulation of glucagon secretion by the intraduodenal administration of phenylalanine during hyperglycaemic clamp experiments (Table 6).

Table 6. Integrated incremental responses of IR-CCK-8-equivalents, IR-GIP, IR-glucagon, and IR-gastrin-17-equivalents to intraduodenal administrations of saline (control), glucose $(333 \mathrm{mg} / \mathrm{min}$ ), or phenylalanine $(333 \mathrm{mg} / \mathrm{min}$ ) during hyperglycaemic (approximately $8 \mathrm{mmol} / \mathrm{l}$ ) clamp experiments. Integrations were carried out over $120 \mathrm{~min}$ (min 60 to 180 , of $180 \mathrm{~min}$ clamp experiments)

\begin{tabular}{|c|c|c|c|c|}
\hline Hormone & Unit & \multicolumn{3}{|c|}{ Intraduodenal administration of: } \\
\hline IR-CCK-8 & $\mathrm{pmol} \cdot 1^{-1} \cdot \min$ & $110 \pm 31$ & $105 \pm 37$ & $455 \pm 58^{\mathrm{a} h}$ \\
\hline IR-glucagon & $\mathrm{pmol} \cdot \mathrm{l}^{-1} \cdot \min$ & $10 \pm 132$ & $-104 \pm 138$ & $201 \pm 140$ \\
\hline IR-gastrin & $\mathrm{pmol} \cdot 1^{-1} \cdot \min$ & $358 \pm 400$ & $219 \pm 71$ & $2002 \pm 887$ \\
\hline
\end{tabular}

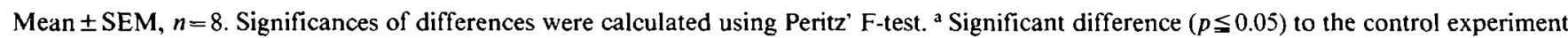
(saline administration). ${ }^{\mathrm{h}}$ Significant difference $(p \leq 0.05)$ to the experiment with intraduodenal glucose administration 
A

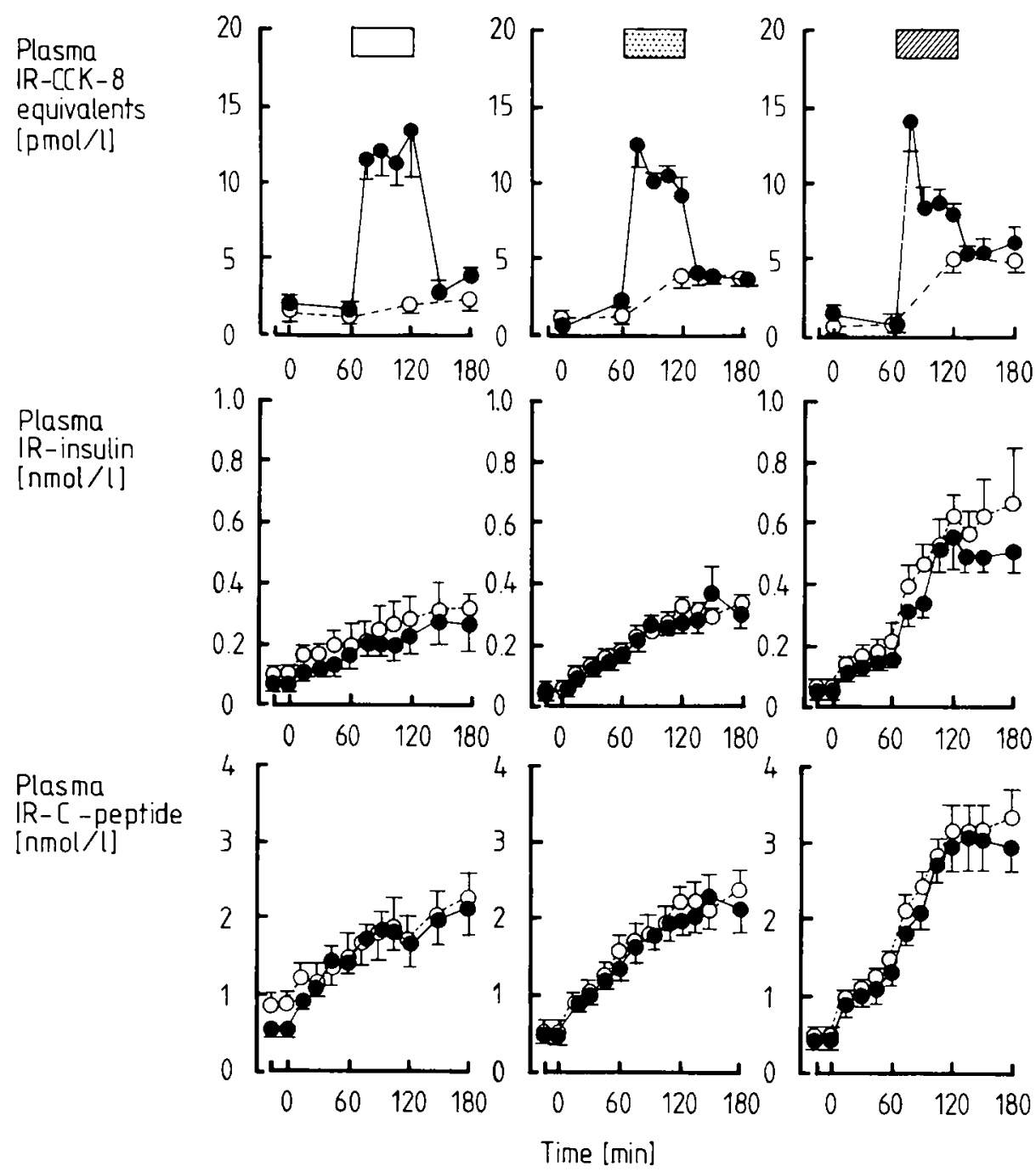

Fig.5. IR-CCK-8 equivalents (upper panels), IR-insulin (middle panels) and IR-C-peptide (lower panels) during 180 min hyperglycaemic clamp experiments (approximately $8 \mathrm{mmol} / \mathrm{l}$ ) with $(-)$ ) or without $(\mathrm{O} \ldots \mathrm{O})$ the intravenous infusion of sulphated CCK-8 $\left(25 \mathrm{pmol} \cdot \mathrm{kg}^{1} \cdot \mathrm{h}^{-1}\right)$ from min 60 to 120 Left panels (A): no intravenous phenylalanine (Protocol c). Middle panels (B): low rate $\left(1.7 \mu \mathrm{mol} \cdot \mathrm{kg}^{1} \cdot \mathrm{min}^{-1}\right)$ intrave nous phenylalanine infusion ( $\mathrm{min} 60$ to 120; Protocol e). Right panels (C): high rate $\left(17 \mu \mathrm{mol} \cdot \mathrm{kg}^{-1} \cdot \mathrm{min}^{-1}\right)$ intravenous phenylalanine infusions (min 60 to 120 ; Protocol f). Mean \pm SEM. Open $L$, dotted $\mathbb{Z}$, and hatched bars indicate period of intravenous phenylalanine and/or CCK-8 administration
Intravenous infusion of sulphated cholecystokinin-8 during hyperglycaemic ( $8 \mathrm{mmol} / \mathrm{l}$ ) clamp experiments. When sulphated CCK- 8 was infused intravenously in the course of a hyperglycaemic clamp experiment, plasma concentrations rapidly reached $11.2 \pm 1.0 \mathrm{pmol} / 1$, and did not change during the period of infusion. Thereafter, a rapid decline to basal levels was observed (Fig. 5 A, upper panel). IR-insulin and IR-C-peptide concentrations were not altered by these CCK-8 concentrations in the upper physiological range, when compared to the hyperglycaemic clamp experiment without CCK infusions, carried out in the same subjects (Fig. 5A, middle and lower panel). The biologic activity of the CCK-8 infused was ascertained by the demonstration of significantly increased bilirubin and trypsin concentrations in duodenal aspirates. The stimulation of exocrine pancreatic secretion and of gall bladder contraction occurred earlier ( $7.5 \mathrm{~min}$ after starting the intravenous infusion of $\mathrm{CCK}$ ) than with intraduodenal administrations of phenylalanine (Table 5).
Intravenous infusions of phenylalanine during hyperglycaemic clamp experiments. Intravenous infusions of phenylalanine elevated plasma phenylalanine concentrations to peak values of $0.13 \pm 0.01 \mathrm{mmol} / \mathrm{l}$ (low infusion rate) or $1.27 \pm 0.04 \mathrm{mmol} / 1$ (high infusion rate) after $60 \mathrm{~min}$ (Fig.1), independent of whether or not CCK-8 was infused concomitantly. With the low phenylalanine infusion rate, IR-insulin and IR-C-peptide concentrations increased only very little over the values observed under hyperglycaemic clamp conditions alone (Fig. 5 B, Table 4). With the higher phenylalanine infusion rate (total amount infused: $12.8 \pm 1.0 \mathrm{~g}$, within $60 \mathrm{~min}$ ), IR-insulin increased to $0.69 \pm 0.16 \mathrm{nmol} / \mathrm{l}$ and IR-C-peptide to $3.38 \pm 0.32 \mathrm{nmol} / \mathrm{l}$. These values were higher than with the lower phenylalanine infusion rate (total amount infused: $1.2 \pm 0.1 \mathrm{~g}$, within $60 \mathrm{~min}$ ), but still lower than those observed with intraduodenal administration of phenylalanine $(20 \mathrm{~g}$ over $60 \mathrm{~min})$. The difference was significant for integrated incremental IR-insulin values $(88.1 \pm 20.4$ versus $38.5 \pm 8.4 \mathrm{nmol}$. $1^{-1} \cdot \min , p=0.02$ ), but not for integrated incremental 
IR-C-peptide values $(220.6 \pm 32.5$ versus $162.2 \pm$ $29.3 \mathrm{nmol} \cdot \mathrm{l}^{-1} \cdot \min , \quad p=0.101$; Table 4 ). The plasma phenylalanine concentrations under these conditions $(20 \mathrm{~g} / \mathrm{h}$ intraduodenally versus $12.8 \pm 1.0 \mathrm{~g} / \mathrm{h}$ intravenously) were similar during the period of phenylalanine administration (min 60 to 120, Fig. 1), but further rose after cessation of intraduodenal infusions (continued presence of phenylalanine in the gut lumen). Both the low and the high rate intravenous phenylalanine infusion increased IR-CCK-8 concentrations significantly, to $3.9 \pm 0.5(p \leqq 0.02)$ and $5.2 \pm 0.8(p \leqq 0.003) \mathrm{pmol} / \mathrm{l}$, respectively. Additional intravenous infusions of sulphated CCK-8, which raised plasma CCK-8 concentrations into the postprandial range (Fig. $5 \mathrm{~B}$ and $\mathrm{C}$, upper panels), did not stimulate insulin secretion further. This lack of action of CCK-8 was evident with a background of moderately or supraphysiologically elevated plasma phenylalanine concentrations.

Intravenous infusion of phenylalanine during basal (euglycaemic) conditions. Like intraduodenal administrations of phenylalanine under basal (euglycaemic) conditions (Table 2), intravenous phenylalanine infusions were followed by minute increases in IR-insulin and IR-C-peptide (Table 4). Phenylalanine concentrations were similar to those during hyperglycaemic experiments (data not shown). Intravenous infusions of CCK-8 did not augment insulin secretion due to intravenous phenylalanine infusions under euglycaemic conditions.

\section{Discussion}

This study confirms that intraduodenal infusions of phenylalanine release $\mathrm{CCK}$ and, thereby, increase the concentration of bilirubin and enzymes in the duodenum $[18,19]$. Simultaneously, plasma levels of insulin and C-peptide only slightly increase. The same intraduodenal infusion of phenylalanine during hyperglycaemic clamp conditions induces a dramatic increase of insulin and C-peptide, while a comparable intraduodenal infusion of glucose $(20 \mathrm{~g} / \mathrm{h})$ is not capable of significantly augmenting insulin secretion. This effect of phenylalanine cannot be related to the release of CCK because an infusion of CCK-8 during hyperglycaemic clamp conditions induced pancreas secretion and gall bladder contraction, but no changes of insulin and C-peptide levels (Fig. $5 \mathrm{~A}$ ).

Glucose-dependent stimulation of insulin secretion of similar magnitude is also seen with intravenous infusions of phenylalanine (Fig. 5, Table 4), which result in plasma concentrations similar to those following intraduodenal administrations of this amino acid. This confirms older studies which demonstrated minor insulin release after large quantities of intravenous phenylalanine under basal conditions [32] and synergistic actions of certain amino acids and glucose $[33,34]$. It cannot be deduced from the present study whether in- traduodenal administration of phenylalanine releases more insulin than does intravenous infusion of the same amount, as shown for amino acid mixtures [35], because the quantities administered aimed at similar plasma concentrations rather than identical amounts. It is not certain, whether additional hormonal factors contribute to the stimulation of insulin secretion after intraduodenal phenylalanine: Integrated incremental responses of insulin and C-peptide were lower after stimulation with intravenous phenylalanine, but only the difference in insulin values was significant (Table 4). This suggests that the activity of the enteroinsular axis $[1,2]$ after intraduodenal phenylalanine under hyperglycaemic conditions is mainly mediated by substrate stimulation. Nevertheless, permissive factors or a combined action of several stimuli have to be discussed.

An elevation of glucose concentrations into the range that corresponds to the maximum plasma levels after oral glucose loads $[5,6]$ or mixed meals $[36]$ is essential for an effect of intraduodenal or intravenous phenylalanine on insulin secretion (Table 4).

The plasma phenylalanine concentrations reached with our regimen of intraduodenal administration were far above those observed postprandially [37] and even after a large oral protein load [38]. Therefore, two regimens of intravenous phenylalanine administration have been studied during hyperglycaemic clamp conditions. The lower infusion rate resulted in phenylalanine concentrations just above those measured after a meat meal [38] and did not significantly augment insulin secretion. On the other hand, phenylalanine administration (intraduodenally, $20 \mathrm{~g}$ over $60 \mathrm{~min}$; intravenously, $12.8 \mathrm{~g}$ over $60 \mathrm{~min}$ ) resulting in supraphysiological plasma levels had an insulinotropic effect. However, 10-fold physiological plasma levels may be considered pharmacological.

With $20 \mathrm{~g}$ of this amino acid administered over a period of $60 \mathrm{~min}$, a small, but significant increase in IR-GIP plasma concentrations was noted (Fig.4), although phenylalanine is among the amino acids that have been reported not to stimulate the release of GIP after their intraduodenal administration [39]. This increase in GIP levels was comparable to the GIP response during intraduodenal infusion of $20 \mathrm{~g}$ glucose over $1 \mathrm{~h}$ which did not significantly augment the insulin secretion during the hyperglycaemic clamp. However, interactions of GIP and amino acids appear possible: insulin release during intravenous administrations of mixed amino acids is enhanced by GIP in dogs [40], and arginine has been shown to augment the effect of GIP on insulin secretion in the isolated perfused rat pancreas [41].

Gastrin was increased by intraduodenal phenylalanine in some, but not in all of the subjects studied (Table 6). Gastrin responses did not correlate to insulin or C-peptide responses, and the maximum concentrations reached was lower than necessary for glucose-de- 
pendent insulinotropic effects [42]. Therefore, a participation of gastrin in the activity of the enteroinsular axis after phenylalanine can be excluded.

Cholecystokinin, under experimental conditions is insulinotropic in rodents [9-12, 43, 44] and dogs [13], but not in pigs [14]. In humans the role of CCK as a stimulus to insulin secretion is less clear. The incretin effect after oral glucose does not involve CCK because there is, at most, a moderate increase in circulating CCK concentrations after a simple carbohydrate challenge [17], and elevated $\mathrm{CCK}$ concentrations maintained by intravenous infusion of CCK- 8 do not enhance the rate of insulin secretion during hyperglycaemic clamp experiments (Fig. $5 \mathrm{~A}$ ) or intravenous glucose infusions [20]. In contrast, exogenous CCK-8 enhanced insulin secretion after either intravenous arginine or mixed amino acid stimulation [20], suggesting that CCK could act as a physiological incretin after mixed meals. However, arginine in a dose of $15 \mathrm{~g}$ is a supraphysiological stimulus to insulin secretion, and also the intravenous infusion of $15 \mathrm{~g}$ mixed amino acids [20] will elevate plasma amino acids more than a mixed meal.

The present study tested possible effects of endogenously secreted CCK (after stimulation via intraduodenal phenylalanine) and of exogenously administered sulphated CCK-8. With intraduodenal phenylalanine as the stimulus, a contribution of $\mathrm{CCK}$ to the large amount of insulin secreted appeared possible. This effect, however, could be largely mimicked by intravenous phenylalanine infusions and the insulin secretion rates could not be changed by additional infusions of CCK (Fig. 5).

After having explained the exaggerated insulin release after intraduodenal phenylalanine under hyperglycaemic conditions, the lack of significant incretin stimulation by intraduodenal glucose needs to be discussed. In previous studies, the incretin stimulation contributed approximately $20 \%$ to insulin secretion after $25 \mathrm{~g}$ oral glucose [6]. In the present study, an even lower amount of glucose was administered. As demonstrated by the small GIP response (Fig.4), a constant, slow intraduodenal administration of $20 \mathrm{~g}$ glucose may stimulate the release of incretin hormones less than a glucose load delivered to the duodenum by gastric emptying.

In conclusion, intraduodenal phenylalanine administrations under hyperglycaemic conditions release more insulin than does the same amount of glucose. Although CCK is released, the stimulation of insulin secretion via the enteroinsular axis is largely due to interactions of elevated glucose and phenylalanine plasma concentrations (substrate stimulation). Exogenous infusion of CCK-8 in physiological concentrations does not augment insulin release induced by intravenous infusions of glucose and phenylalanine. These results do not support a role as an incretin hormone for cholecystokinin in man.
Acknowledgements. The expert technical assistence of A. v. Baumbach, U.E.Laubner, B. Feddersen, W. Kopp, A. Bernhardt, S. Beck, K. Illmer, and H.Keller is gratefully acknowledged. We thank Dr. W. Voss, Ms. B. Roth, and Ch. Bierwirth of the Department of Pediatrics, Georg-August-University, Göttingen, for the measurements of plasma amino acids.

\section{References}

1. Unger RH, Eisentraut A.M (1969) Entero-insular axis. Arch Intern Med 123: 261-266

2. Creutzfeldt W, Ebert $R$ (1986) The enteroinsular axis. In: Go VLW (ed) The exocrine pancreas: biology, pathobiology, and diseases. Raven Press, New York

3. Creutzfeldt W (1979) The incretin concept today. Diabetologia 16: $75-85$

4. Creutzfeldt W, Ebert R (1985) New developments in the incretin concept. Diabetologia 28: 565-573

5. Nauck M, Stöckmann F, Ebert R, Creutzfeldt W (1986) Reduced incretin effect in Type 2 (non-insulin-dependent) diabetes. Diabetologia $29: 46-52$

6. Nauck MA, Homberger E, Siegel E, Allen RC, Eaton RP, Ebert R, Creutzfeldt W (1986) Incretin effects of increasing glucose loads in man calculated from venous insulin and C-peptide responses. J Clin Endocrinol Metab 63: 492-498

7. Creutzfeldt W, Ebert R (1976) Release of gastric inhibitory polypeptide (GIP) to a test meal under normal and pathological conditions in man. Excerpta Medica Intemational Congress Series No.413. Diabetes. Excerpta Medica, Amsterdam

8. Elahi D, Andersen DK, Brown JC, Debas HT, Hershkopf RJ, Raizes GS, Tobin JI), Andres R (1979) Pancreatic $\alpha$ - and $\beta$-cell responses to GIP infusion in normal man. Am $J$ Physiol 237: E $185 \cdots 191$

9. Sakamoto C, Otsuki M, Ohki A, Yuu H, Yamasaki T, Baba S (1982) Glucose dependent insulintropic action of cholecystokinin and cacrulein in isolated perfused rat pancreas. Endocrinol 110: $398-402$

10. Zawalich WS, Cote SB, Diaz VA (1986) Influence of cholecystokinin on insulin output from perifused pancreatic islcts. Endocrinol 119: 616-621

11. Szecokwa J, Lins PE, Efendic S (1982) Effects of cholecystokinin, gastric inhibitory polypeptide, and secretin on insulin and glucagon secretion in rats. Fndocrinol 110: $1268-1272$

12. Rossetti L, Shulman GI, Zawalich WS (1987) Physiological role of cholecystokinin in meal-induced insulin secretion in conscious rats: studies with L 364718 , a specific inhibitor of CCK-receptor binding. Diabetes $36: 1212-1215$

13. Hermansen K (1984) Effects of Cholecystokinin (CCK)-4, Nonsulfated CCK-8, and sulfated CCK-8 on pancreatic somatostatin, insulin, and glucagon secretion in the dog: studies in vitro. Fndocrinol 114: 1770-1775

14. Lindkaer Jensen S, Rehfeld JF, Holst JJ, Nielsen OV, Fahrenkrug J, Schaffalitzky de Muckadell OB (1981) Secretory effects of cholecystokinins on the isolated perfused porcine pancreas. Acta Physiol Scand 111: 225-231

15. Sakamoto C, Goldfine ID, Roach E, Williams JA (1985) Localization of saturable binding sites in rat pancreatic islets by light and electron microscope autoradiography. Diabetes 34: 390-394

16. Verspohl EJ, Ammon HPT, Williams JA, Goldfine ID (1986) Evidence that cholecystokinin interacts with specific reccptors and regulates insulin release in isolated rat islets of Langerhans. Diabetes $35: 38-43$

17. Liddle RA, Goldfine ID, Rosen MS, Taplitz RA, Williams JA (1985) Cholecystokinin bioactivity in human plasma. Molecular forms, responses to feeding, and relationship to gallbladder contraction. J Clin Invest 75: 1144-1152

18. Owyang C, Louie DS, Tatum D (1986) Feedback regulation of pancreatic enzyme secretion. Suppression of Cholecystokinin release by trypsin. J Clin Invest 77: 2042-2047 
19. Go VLW, Hofmann AF, Summerskill WHJ (1970) Pancreozymin bioassay in man based on pancreatic enzyme secretion: potency of specific amino acids and other digestive products. J Clin Invest 49: 1558-1564

20. Rushakoff RJ, Goldfine ID, Carter JD, Liddle RA (1987) Physiological concentrations of cholecystokinin stimulate amino-acid induced insulin release in humans. J Clin Endocrinol Metab 65: 395-401

21. DeFronzo RA, Tobin JD, Andres R (1979) Glucose clamp technique: a method for quantifying insulin secretion and resistance. Am J Physiol 237: E 214-223

22. Melani F, Ditschuneit $H$, Bartelt HM, Friedrich $H$, Pfeiffer EF (1965) Über die radioimmunologische Bestimmung von Insulin im Blut. Klin Wochenschr 43: 1000-1006

23. Cantor $P(1986)$ Evaluation of a radioimmunoassay for cholecystokinin in human plasma. Scand J Lab Clin Invest 46: 213-221

24. Kuzio M, Dryburgh JR, Malloy KM, Brown JC (1974) Radioimmunoassay for gastric inhibitory polypeptide. Gastroenterol 66 : 357-364

25. Ebert R, Illmer K, Creutzfeldt W (1979) Release of gastric inhibitory polypeptide (GIP) by intraduodenal acidification in rats and humans and abolishment of the incretin effect of acid by GIP-antiserum in rats. Gastroenterol 76: 515-523

26. Mayer G, Arnold R, Feurle G, Fuchs K, Ketterer H, Track NS, Creutzfeldt W (1974) Influence of feeding and sham feeding upon serum gastrin and gastric acid secretion in control subjects and duodenal ulcer patients. Scand J Gastroenetrol 9:703 710

27. Jendrassik L, Graf O (1938) Vereinfachte Methoden zur Bestimmung des Blutbilirubins. Biochem Zeitschr 297: 6-15

28. Erlanger BF, Kokonsky N, Cohen W (1961) The preparation and properties of two new chromogenic substrates of trypsin. Arch Biochem Biophys 95: 271-278

29. Rick W, Stegbauer HP (1970) $a$-dmylase-Messung der reduzierenden Gruppen. In: Bergmeyer HU (ed) Methoden der enzymatischen Analyse, Vol 1, 2nd edn. Verlag Chemie, Weinheim

30. Harper JF (1984) Peritz' F test: basic program of a robust multiple comparison test for statistical analysis of all differences among group means. Comput Biol Med 14: 437-445

31. Doberne L, Greenfield MS, Schulz B, Reaven GM (1981) Fnhanced glucose utilization during prolonged glucose clamp studies. Diabetes 30: 829-835

32. Floyd JC, Fajans S, Conn JW, Knopf RF, Rull J (1966) Stimulation of insulin secretion by amino acids. J Clin Invest 45 : 1487-1502

33. Floyd JC, Fajans SS, Pek S, Thiffault CA, Knopf RF, Conn JW (1970) Synergistic effect of essential amino acids and glucose upon insulin secretion in man. Diabetes 19: 109-115

34. Levin SR, Karam JH, Hane S, Grodsky GM, Forsham PH (1971) Enhancement of arginine-induced insulin secretion by prior administration of glucose. Diabetes 20: 171-176

35. Raptis S, Dollinger HC, Schroeder KE, Schleyer M, Rotherbuchner G, Pfeiffer EF (1973) Differences in insulin, growth hormone and pancreatic enzyme secretion after intravenous and intraduodenal administration of mixed amino acids in man. New Engl J Med 288: 1199-1202

36. Swislocki ALM, Donner CC, Fraze E, Chen YDI, Reaven GM (1987) Can insulin resistance exist as a primary defect in noninsulin-dependent Diabetes mellitus? J Clin Endocrinol Metab 64: 778-782

37. Wurtman RJ, Rose CM, Chou C, Larin FF (1968) Daily rhythms in the concentrations of various amino acids in human plasma. N Engl J Med 279: 171-175

38. Schauder P, Schroeder K, Langenbeck U (1984) Serum branched chain amino and keto acid response to a protein rich meal in man. Ann Nutr Metab 28: 350-356

39. Thomas FR, Sinar D, Mazzaferri EL, Cataland S, Mekhjian HS, Caldwell JH, Sromkes X (1978) Selective release of gastric inhibitory polypeptide by intraduodenal amino acid perfusion in man. Gastroenterol 74: 1261 - 1265

40. Yovos JG, O'Dorisio TM, Pappas TN, Cataland S, Thomas FB, Mekhjian H, Carey LC (1982) Effects of amino acids and gastric inhibitory polypeptide on insulin release in dogs. Am J Physiol 242: E 53-E 58

41. Pederson RA, Brown JC (1978) Interaction of gastric inhibitory polypeptide, glucose, and arginine on insulin and glucagon secretion from the perfused rat pancreas. Endocrinol 103: 610-615

42. Rehfeld JF, Stadil F (1973) The effect of gastrin on basal- and glucose-stimulated insulin secretion in man. J Clin Invest 52: $1415-1426$

43. Fujimoto WY, Williams RH, Ensinck JW (1979) Gastric inhibitory polypeptide (GIP) and cholecystokinin, and secretin effects on insulin and glucagon secretion by islet cultures. Proc Soc Exp Biol Med 160: 349-353

44. Ahren B, Hedner P, Lundquist I (1983) Interaction of gastric inhibitory polypeptide (GIP) and cholecystokinin (CCK-8) with basal and stimulated insulin secretion in mice. Acta Endocrinol 102: $96-102$

45. Nauck M, Reimers J, Ebert R, Cantor P, Creutzfeldt W (1987) Insulinotropic effect of endogenous and exogenous cholecystokinin in man. Diabetologia 30: $561 \mathrm{~A}$

46. Creutzfeldt W, Reimers J, Nauck M, Ebert R, Cantor P (1987) CCK mediates increased exocrine but not endocrine secretion after intraduodenal phenylalanine. Dig Dis Sci 32: 1162 (A-5)

Received: 13 July 1987

and in revised form: 9 March 1988

Prof. Dr. W. Creutzfeldt

Division of Gastroenterology and Endocrinology

Department of Medicine

Georg August University

Robert-Koch-Strasse 40

D-3400 Göttingen

FRG 